Diabetologia (1990) 33: 93-99

\title{
Cellular cholesterol regulation - A defect in the Type 2 (non-insulin-dependent) diabetic patient in poor metabolic control
}

\author{
D. Owens ${ }^{1}$, V. Maher ${ }^{1}$, P. Collins ${ }^{1}$, A. Johnson ${ }^{1}$ and G. Tomkin ${ }^{2}$ \\ ${ }^{1}$ Department of Biochemistry, Royal College of Surgeons in Ireland, and ${ }^{2}$ The Adelaide Hospital, Dublin, Ireland
}

\begin{abstract}
Summary. This study investigates the relationship between Type 2 (non-insulin-dependent) diabetes mellitus and hypercholesterolaemia with regard to delivery of cholesterol to cells and regulation of endogenous cholesterol synthesis. The ability of LDL, from hypercholesterolaemic and Type 2 diabetic patients, to suppress cellular cholesterologenesis and to enhance mitogen-stimulated lymphocyte proliferation was compared. Cholesterol synthesis was estimated by measuring $\left[{ }^{14} \mathrm{C}\right]$-acetate incorporation into cholesterol and lymphocyte proliferation was assessed by $\left[{ }^{3} \mathrm{H}\right]$-thymidine incorporation into mitogen-stimulated normal lymphocytes. The results indicate that LDL from both Type 2 diabetic patients in poor metabolic control and hypercholesterolaemic patients was significantly less effective $(p<0.001)$ than LDL from non-diabetic normocholesterolaemic subjects in suppressing cholesterol synthesis in lymphocytes. LDL from all
\end{abstract}

hypercholesterolaemic patients enhanced lymphocyte proliferation to a greater extent than LDL from normocholesterolaemic subjects and this effect was significantly increased using LDL from Type 2 diabetic, hypercholesterolaemic patients. Both suppression of $\left[{ }^{14} \mathrm{C}\right]$-acetate incorporation and enhancement of $\left[{ }^{3} \mathrm{H}\right]$-thymidine uptake could be related to an increased esterified/free cholesterol ratio in the LDL particle. The fact that cholesterol synthesis and cell proliferation were markedly altered by the above changes in LDL composition suggests a mechanism for cellular cholesterol accumulation in the Type 2 diabetic patient, even in the absence of elevated serum cholesterol levels.

Key words: Type 2 (non-insulin-dependent) diabetes mellitus, LDL, cholesterol, esterification, glycosylation.
Vascular disease is a common complication of diabetes mellitus. Elevated low density lipoprotein (LDL) cholesterol is associated with atherosclerosis in the general population and while there is evidence that prolonged hyperglycaemia may increase LDL $[1,2]$ a simple relationship has not been established between atherosclerosis in diabetes and high serum cholesterol levels.

Rapidly dividing cells exhibit an increased demand for cholesterol and lymphocytes, being easily accessable, readily inducable to growth and representative of many cell types, provide an ideal system in which to evaluate cellular cholesterol homeostasis. A delicate system, in which LDL plays a central role, is responsible for regulation of cholesterol homeostasis [3]. Cholesterol, delivered to peripheral cells by LDL, in turn inhibits endogenous cholesterologenesis and down-regulates LDL receptors on the cell surface. LDL has also been implicated in immunoregulation $[4,5]$ and has been shown to both enhance and inhibit proliferation of a variety of cell types in culture [6].
In diabetes, non-enzymatic glycosylation of LDL accompanies hyperglycaemia $[7,8]$ with resultant alteration in its metabolism. Compositional changes in the LDL particle, particularly with respect to triglyceride $[9,10]$ have been shown to interfere with its binding to the cell surface receptor [11] and are known to affect its metabolism although the mechanism has not been clearly demonstrated at a cellular level.

In Type 2 diabetic patients we have demonstrated an elevation of lymphocyte 3-hydroxy-3-methylglutaryl coenzyme A (HMGCoA) reductase, the rate-limiting enzyme for cholesterol synthesis [12]. The increase in HMGCoA reductase correlated with the degree of hyperglycaemia suggesting a defect in the synthesis or regulation of the enzyme in Type 2 diabetic patients in poor metabolic control. The present study looks at the effect of changes in LDL composition, accompanying hypercholesterolaemia and poor diabetes control, on the ability of the lipoprotein to stimulate lymphocyte proliferation by delivery of cholesterol to cells and to regulate cellular cholesterol synthesis. 
Table 1. Subjects

\begin{tabular}{lllll}
\hline Non-diabetic & $n$ & $\begin{array}{l}\text { Serum } \\
\text { cholesterol } \\
(\mathrm{mmol} / \mathrm{l})\end{array}$ & $\begin{array}{l}\text { Serum } \\
\text { triglyceride } \\
(\mathrm{mmol} /)\end{array}$ & $\begin{array}{l}\mathrm{HbA}_{1} \\
\text { (mor }\end{array}$ \\
\hline $\begin{array}{l}\text { Normocholesterolaemic } \\
\text { Hypercholesterolaemic }\end{array}$ & 14 & $5.2 \pm 0.5$ & $1.06 \pm 0.2$ & $<7.0$ \\
$\begin{array}{l}\text { Type 2 (non-insulin- } \\
\text { dependent) diabetic }\end{array}$ & & & & \\
$\begin{array}{l}\text { Normocholesterolaemic } \\
\text { Good metabolic control }\end{array}$ & 8 & $5.1 \pm 0.5$ & $1.89 \pm 0.3$ & $7.3 \pm 0.3$ \\
$\begin{array}{l}\text { Poor metabolic control } \\
\text { Hypercholesterolaemic }\end{array}$ & 6 & $5.3 \pm 0.6$ & $2.11 \pm 0.5$ & $11.7 \pm 0.8$ \\
$\begin{array}{l}\text { Good metabolic control } \\
\text { Poor metabolic control }\end{array}$ & 9 & $8.6 \pm 1.2$ & $2.01 \pm 0.3$ & $7.2 \pm 0.3$ \\
\hline
\end{tabular}

\section{Subjects, materials and methods}

\section{Subjects}

Twenty-eight Type 2 (non-insulin-dependent) diabetic patients, 14 of whom were normocholesterolaemic (serum cholesterol $<6.5$ $\mathrm{mmol} / \mathrm{l}$ ) and 14 hypercholesterolaemic (serum cholesterol $>6.5$ $\mathrm{mmol} / \mathrm{l}$ ) were enrolled from patients attending the diabetic clinic. Of the patients 16 were male and 12 female and their mean age \pm SEM was $57 \pm 2.7$ years. None of the patients had a known history of hyperlipidaemia and patients who smoked were excluded from the study. Nine patients had background mild retinopathy, 5 had proliferative retinopathy, 2 suffered from hypertension and one had ischaemic heart disease. Twenty-one of the patients were receiving oral hypoglycaemic agents. Five of these were treated with metformin and 16 were on oral sulphonylurea drug treatment. One patient was receiving insulin and the remainder were treated with diet. These patients were age and sex matched with 14 normocholesterolaemic non-diabetic volunteers and 14 non-diabetic hypercholesterolaemic patients attending the lipid clinic who had similar serum cholesterol levels to their diabetic counterparts (Table 1). All subjects gave informed consent and the study was approved by the ethics committee of the Adelaide Hospital, Dublin.

\section{Lipoprotein preparation and analysis}

Blood was taken by venepuncture from fasting individuals at 09.00 hours each morning and the plasma sample was subjected to ultracentrifugation at $4{ }^{\circ} \mathrm{C}$ within $1 \mathrm{~h}$ of collection. LDL (density
$1.025-1.060 \mathrm{~g} / \mathrm{ml}$ ) and lipoprotein deficient serum (LDS) (density $>1.215 \mathrm{~g} / \mathrm{ml}$ ) were isolated from plasma or serum by sequential ultracentrifugation [13]. The density band used to isolate LDL, which was slightly narrower than the usual one (density 1.019-1063 $\mathrm{g} / \mathrm{ml}$ ) was selected to ensure that LDL, was free from contamination with other lipoproteins. The position of the band is known to vary slightly between normal subjects [14] and even minor contamination with apolipoprotein E-containing lipoproteins could profoundly influence the apparent binding of LDL to lymphocytes [15]. Following exhaustive dialysis against $0.15 \mathrm{~mol} / \mathrm{NaCl} / 0.05 \%$ EDTA, LDL was sterilised by filtration ( $0.22 \mu$ Millex-GV filter, Millipore, Middlesex, UK) and its purity confirmed by polyacrylamide gel electrophoresis [16]. It was stored at $4{ }^{\circ} \mathrm{C}$ and used within one month. LDS was heatinactivated, centrifuged, filtered and stored at $-20^{\circ} \mathrm{C}$.

Serum total cholesterol and LDL total and free cholesterol levels were measured by enzymatic colorimetric methods using kits from Boehringer Mannheim GmbH (Mannheim, FRG) and LDL triglyceride and phospholipid levels with kits from Biomerieux (Charbonnieres les Bains, France). Protein was determined by a modification of the Lowry method [17] and $\mathrm{HbA}_{1}$ was determined as the percentage of total $\mathrm{Hb}$ following ion exchange chromatography using commercial kits (Boehringer Mannheim $\mathrm{GmbH}$ ).

\section{Glycosylation}

LDL was glycosylated in vitro by incubating LDL (2.0 $\mathrm{mg}$ LDL protein $/ \mathrm{ml})$ for 7 days with glucose $(90 \mathrm{mmol} / \mathrm{l})$ as described by Lyons et al. [18]. Glycosylation of LDL was measured by affinity chromatography using aminophenylborate gel [19].

\section{Cell preparation and culture}

Lymphocyte-enriched peripheral blood mononuclear cells (PBMC) were separated from heparinised blood by centrifugation on Ficoll/hypaque gradients (density $1.076 \mathrm{~g} / \mathrm{ml}$ ) using a modification of the method of Boyum $[20,21]$. Cells were examined microscopically following staining with acridine orange $(0.5 \mathrm{mg} \%$ weight/volume [w/v]), ethidium bromide (0.5 mg\% w/v) (BDH, Poole, UK). PBMC isolated by this method were $>85 \%$ lymphocytes, the remainder being monocytes. Cells were $>99 \%$ viable using this staining procedure.

PBMC $\left(2 \times 10^{6} / \mathrm{ml}\right)$ were cultured in RPMI 1640 medium (Gibco Ltd. Paisley, Scotland, UK) containing penicillin $(100 \mathrm{U} / \mathrm{ml})$, streptomycin $(100 \mu \mathrm{g} / \mathrm{ml})$ and LDS $(10 \%$ volume/volume $[\mathrm{v} / \mathrm{v}])$ in the presence of phytohaemagglutinin (PHA) $(1 \mu \mathrm{g} / \mathrm{ml})(\mathrm{PHA}-16$, Wellcome Diagnostics, Oxford, UK) at $37^{\circ} \mathrm{C}$ in a humidified atmosphere

Table 2. Low density lipoprotein composition ratios (mg/mg)

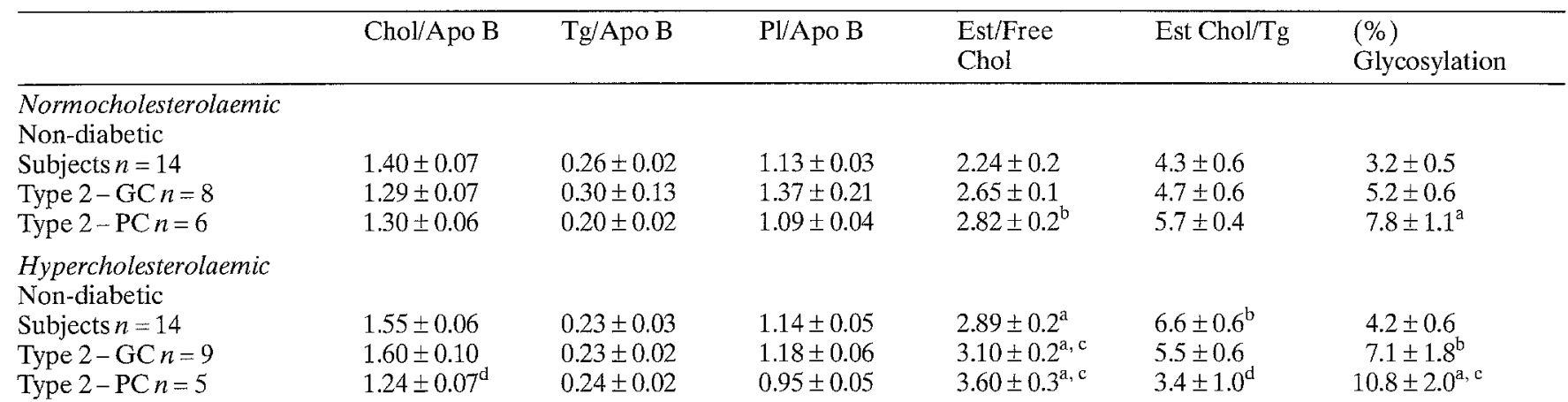

Type 2 - GC - Type 2 (non-insulin-dependent) diabetic patients in good metabolic control. Type 2 - PC - Type 2 diabetic subjects in poor metabolic control.

${ }^{\mathrm{a}}=p<0.002,{ }^{\mathrm{b}}=p<0.02$ Different from normocholesterolaemic, non-diabetic subjects. ${ }^{\mathrm{c}}=p<0.02$ Different from normocholesterolaemic Type 2 diabetic patients in good metabolic control. ${ }^{d}=p<0.01$ Different from hypercholesterolaemic, non-diabetic subjects. Apo $\mathrm{B}=$ apolipoprotein $\mathrm{B}$; Chol = cholesterol; Est = esterified; $\mathrm{Pl}=$ phospholipid; $\mathrm{Tg}=$ triglyceride 


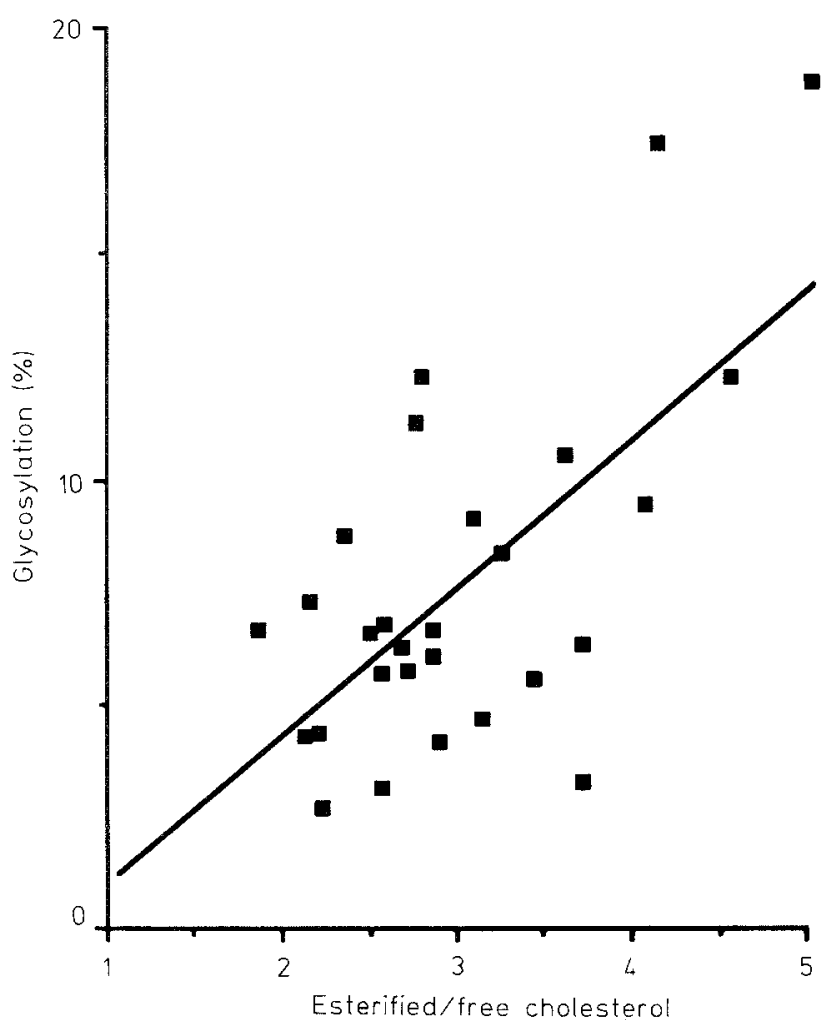

Fig.1. Relationship between non-enzymatic glycosylation of LDL from Type 2 (non-insulin-dependent) diabetic patients $(n=28)$ and the esterified/free cholesterol ratio of the LDL. $(r=0.61, p<0.001)$

of $5 \% \mathrm{CO}_{2}$ in air. LDS, isolated from the plasma of the same donor, was used throughout the study. LDL $(2.5-10 \mu \mathrm{g}$ protein $/ \mathrm{ml})$ from $\mathrm{pa}-$ tients or control subjects was added to the culture after $48 \mathrm{~h}$, cells were harvested at $67 \mathrm{~h}$ and cholesterol synthesis was measured by $\left[{ }^{14} \mathrm{C}\right]$-acetate incorporation into cholesterol.

\section{Cholesterolsynthesis}

In the absence of lipoprotein, cells synthesise cholesterol from acetate. $\left[{ }^{14} \mathrm{C}\right]$-acetate incorporation into lymphocytes was estimated as described by $\mathrm{Ho}$ et al. [22]. Lymphocytes were washed to remove PHA, resuspended in fresh medium at $2 \times 10^{7}$ cells $/ \mathrm{ml}$ and incubated for $5 \mathrm{~h}$ with $\left[1-{ }^{14} \mathrm{C}\right]$-acetate $(1 \mathrm{mmol} / \mathrm{l})$. Following saponification, sterols were extracted, separated by thin-layer chromatography and quantified by liquid scintilation counting. Results were expressed as pmol acetate incorporated $\cdot \mathrm{min}^{-1} \cdot \mathrm{mg}^{-1}$ cell protein.

\section{Lymphocyte proliferation}

Lymphocyte proliferation was measured by $\left[{ }^{3} \mathrm{H}\right]$-thymidine incorporation into mitogen-stimulated lymphocytes [23]. PHA-stimulated lymphocytes $\left(5 \times 10^{5} / \mathrm{ml}\right)$ were cultured in RPMI supplemented with LDS $(1 \% \mathrm{v} / \mathrm{v})$ and penicillin/streptomycin. Cells were rendered dependent on an exogenous supply of cholesterol by the addition of mevinolin $(1 \mu \mathrm{mol} / 1)$ (Sigma, Poole, UK), a specific inhibitor of IMGCoA reductase, to the cell cultures. Cholesterol, in the form of LDL, from the different patient groups was then added to the cultures in varying concentrations $(1.25-10 \mu \mathrm{g}$ protein $/ \mathrm{ml})$ and its capacity to support cell proliferation was assessed after $72 \mathrm{~h}$ by measuring $\left[{ }^{3} \mathrm{H}\right]$-thymidine incorporation. Results were expressed as degree of stimulation of $\left[{ }^{3} \mathrm{H}\right]$-thymidine uptake by LDL using uptake in the absence of LDL as baseline.

\section{Statistical analysis}

Statistical analysis was performed using ANOVA analysis of variance and the unpaired Students $t$-test. Correlation coefficients were determined by linear regression analysis. Results were expressed as means \pm SEM unless otherwise stated. A $p$ value of $<0.05$ was regarded as statistically significant.

\section{Results}

Type 2 diabetic patients were classified on the basis of their $\mathrm{HbA}_{1}$ levels into good metabolic control $\left(\mathrm{HbA}_{1}<8.5 \%\right)$ or poor metabolic control $\left(\mathrm{HbA}_{1}>8.5 \%\right)$. There was no significant difference in the mean serum cholesterol level between the three normocholesterolaemic groups, nor was there any significant difference between the mean serum cholesterol levels in the hypercholesterolaemic groups (Table 1).

\section{Lipoprotein composition}

The elemental composition of LDL, expressed as a ratio of lipid: apolipoprotein B (apo B), the esterified/free cholesterol ratio, the esterified cholesterol/triglyceride ratio and the extent of glycosylation of the different LDL preparations are shown in Table 2. With the exception of the decreased cholesterol/apo B ratio in LDL from the hypercholesterolaemic Type 2 diabetic patients in poor metabolic control there were no significant differences in the lipid/apo B ratios between LDL from the various groups. The ratio of esterified/free cholesterol was found to be significantly increased in LDL from both Type 2 diabetic and non-diabetic hypercholesterolaemic patients $(p<0.002)$ and in normocholesterolaemic Type 2 diabetic patients in poor metabolic control $(p<0.02)$ compared with normocholesterolaemic non-diabetic subjects. The

Table 3. Effect of diabetic control on LDL inhibition of $\left[{ }^{14} \mathrm{C}\right]$-acetate incorporation

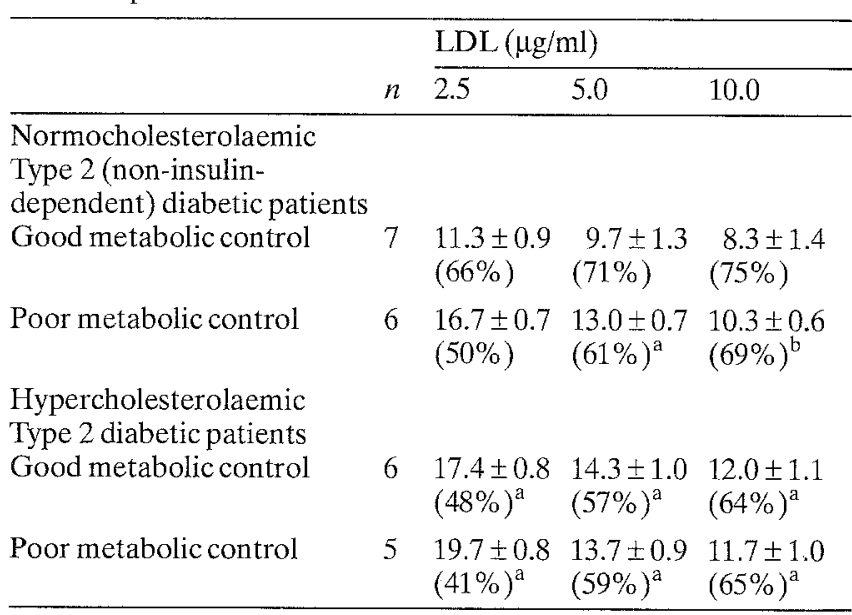

Results expressed as pmol acetate $\cdot \mathrm{min}^{-1} \cdot \mathrm{mg}^{-1}$ cell protein $(\%$ inhibition). $\left[{ }^{14} \mathrm{C}\right]$-acetate incorporation in the absence of $\mathrm{LDL}=$ $33.2 \pm 4.6(0 \%$ inhibition $)$

${ }^{\mathrm{a}}=p<0.001,{ }^{\mathrm{b}}=p<0.01$ different from normocholesterolaemic, Type 2 diabetic patients in good metabolic control 


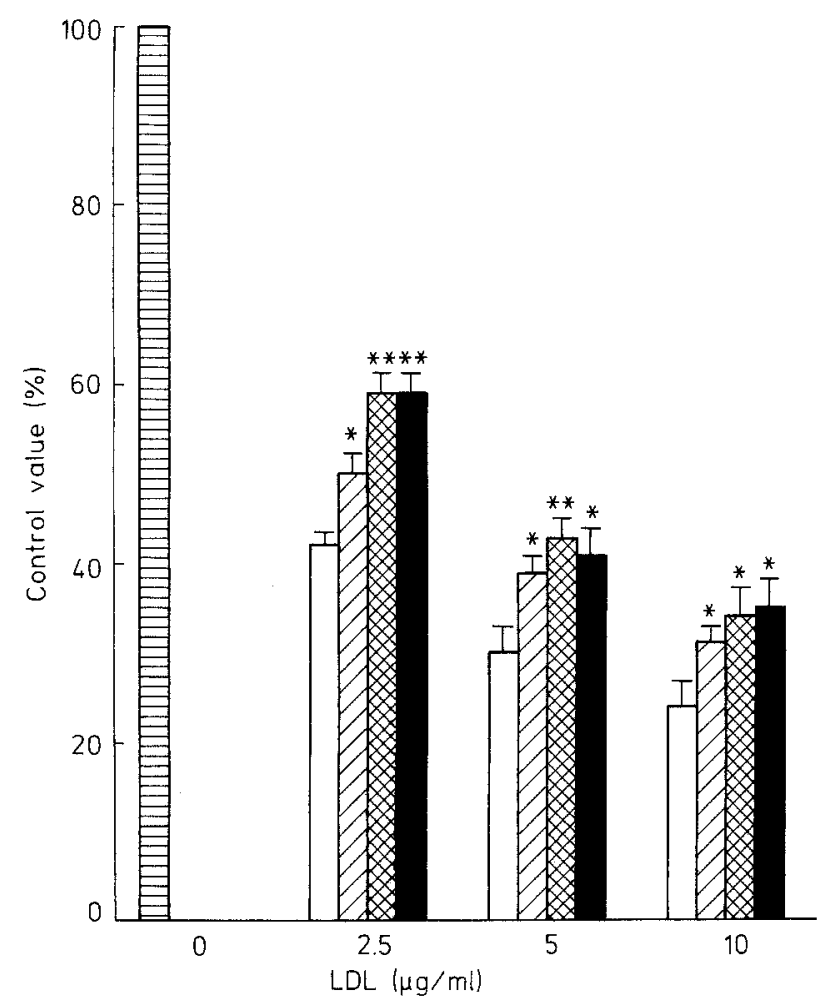

Fig. 2. Suppression of $\left[{ }^{14} \mathrm{C}\right]$-acetate incorporation into cholesterol by LDL added to PHA-stimulated lymphocytes following $48 \mathrm{~h}$ culture in lipoprotein-deficient serum (LDS). Cells were harvested at $67 \mathrm{~h}$ and $\left[{ }^{14} \mathrm{C}\right]$-acetate incorporation measured over a further $5 \mathrm{~h}$. Results are expressed as \% control value $\left(\left[{ }^{14} \mathrm{C}\right]\right.$-acetate incorporation in the absence of $\mathrm{LDL}=100 \%$ ) error bars indicate SEM. $* *=p<0.001$, $*=p<0.01$ different from non-diabetic normocholesterolaemic subjects. No LDL, horizontal bars: LDL from non-diabetic subjects $(n=12)$, open bar: LDL from normocholesterolaemic Type 2 diabetic patients $(n=13)$, hatched bar: LDL from hypercholesterolaemic non-diabetic subjects $(n=8)$, cross-hatched bar: LDL from hypercholesterolaemic Type 2 diabetic patients $(n=11)$, black bar

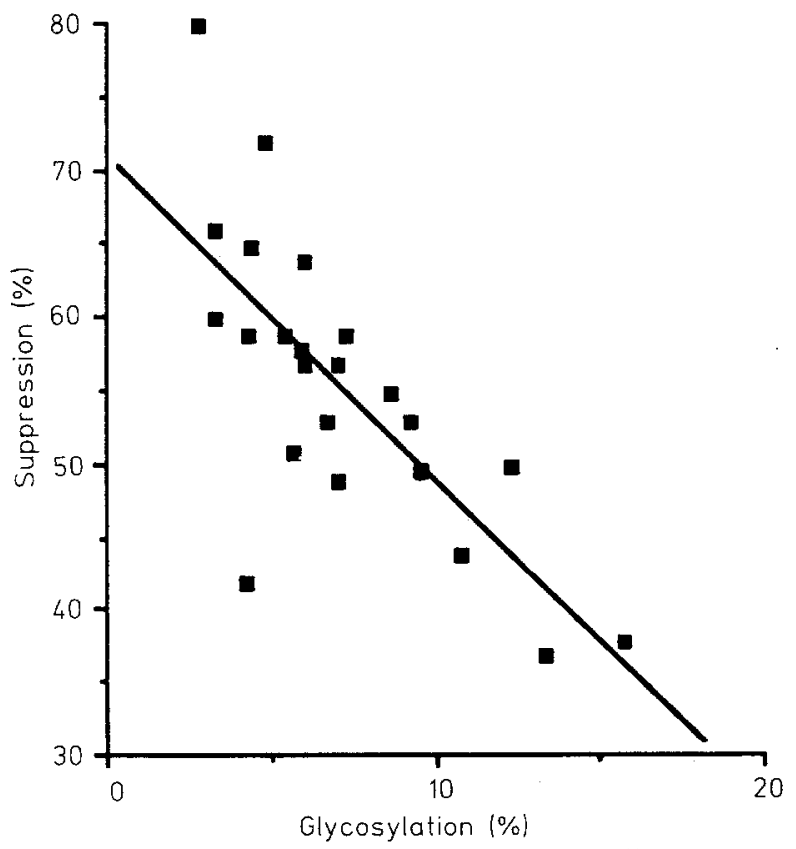

Fig. 3. Correlation between $\%$ suppression of $\left[{ }^{14} \mathrm{C}\right]$-acetate incorporation into lymphocyte cholesterol by $\operatorname{LDL}(2.5 \mu \mathrm{g} / \mathrm{ml})$ from Type 2 (non-insulin-dependent) diabetic patients $(n-24)$ and the degree of LDL glycosylation $(r=-0.74, p<0.001)$ cholesterol ester to triglyceride ratio in LDL from the hypercholesterolaemic patients was significantly higher than that in the normocholesterolaemic non-diabetic subjects $(p<0.02)$ while the ratio in the hypercholesterolaemic Type 2 diabetic patients in poor metabolic control was lower than that in the non-diabetic hypercholesterolaemic patients $(p<0.02)$. Non-enzymatic glycosylation was increased in LDL from all Type 2 diabetic patients in poor metabolic control and the increase was most evident in the hypercholesterolaemic patients in poor metabolic control $(p<0.002)$. Glycosylation was also raised in LDL from the Type 2 diabetic patients in good metabolic control who were hypercholesterolaemic. There was a positive correlation $(r=0.61, p<0.001)$ between the degree of glycosylation of LDL from Type 2 diabetic subjects $(n=28)$ and the esterified/free cholesterol ratio in the LDL (Fig.1).

\section{$\left.\int^{14} \mathrm{C}\right]$-Acetate incorporation}

Cells normally derive their cholesterol in part from circulating lipoproteins. When cultured under lipoproteindeficient conditions however, lymphocytes are capable of synthesising sufficient cholesterol from acetate to maintain growth and division. PHA-stimulated lymphocytes, cultured for $72 \mathrm{~h}$ in medium supplemented with lipoprotein-deficient serum, were found to incorporate 10 times more $\left[{ }^{14} \mathrm{C}\right]$-acetate than unstimulated cells. The effect of exposure of the cells to LDL for the final $24 \mathrm{~h}$ of culture was to suppress $\left[{ }^{14} \mathrm{C}\right]$-acetate incorporation by up to $70 \%$ (Fig. 2). This suppression of $\left[{ }^{14} \mathrm{C}\right]$-acetate uptake was concentration-dependent in the range $2.5-10 \mu \mathrm{g} / \mathrm{ml} \mathrm{LDL}$ and was seen in all LDL samples. The degree of inhibition however, varied considerably depending on the source of the LDL. At each LDL concentration tested, a significantly higher degree of inhibition was obtained with $\mathrm{LDL}$ derived from normocholesterolaemic non-diabetic subjects relative to that obtained with LDL from both Type 2 diabetic categories $(p<0.001)$ and from hypercholesterolaemic non-diabetic subjects $(p<0.01)$.

The influence of diabetic control on the capacity of LDL to suppress $\left[{ }^{14} \mathrm{C}\right]$-acetate incorporation into cholesterol is shown in Table 3. It is evident that LDL from hyperglycaemic patients has an impaired ability to suppress cholesterol synthesis. LDL from hypercholesterolaemic Type 2 diabetic patients is also less effective in this regard and when patients are both hypercholesterolaemic and in poor metabolic control their LDL is least effective of all $(p>0.001)$. This ability of the LDL sample to suppress $\left[{ }^{14} \mathrm{C}\right]$-acetate uptake into lymphocyte cholesterol correlated negatively to a highly significant extent $(r=-0.74, p<0.001)$ with the degree of glycosylation of LDL from these Type 2 diabetic subjects (Fig. 3).

A sample of LDL was glycosylated in vitro, raising the level of glycosylation from $1.6 \%$ to $30 \%$. When this LDL was compared with a sample of the same LDL which had been incubated without glucose a similar degree of inhibition of $\left[{ }^{14} \mathrm{C}\right]$-acetate incorporation was observed. LDL$1.6 \%$ glycosylated $(2.5,5.0$, and $10.0 \mu \mathrm{g}$ protein $/ \mathrm{ml})$ gave 


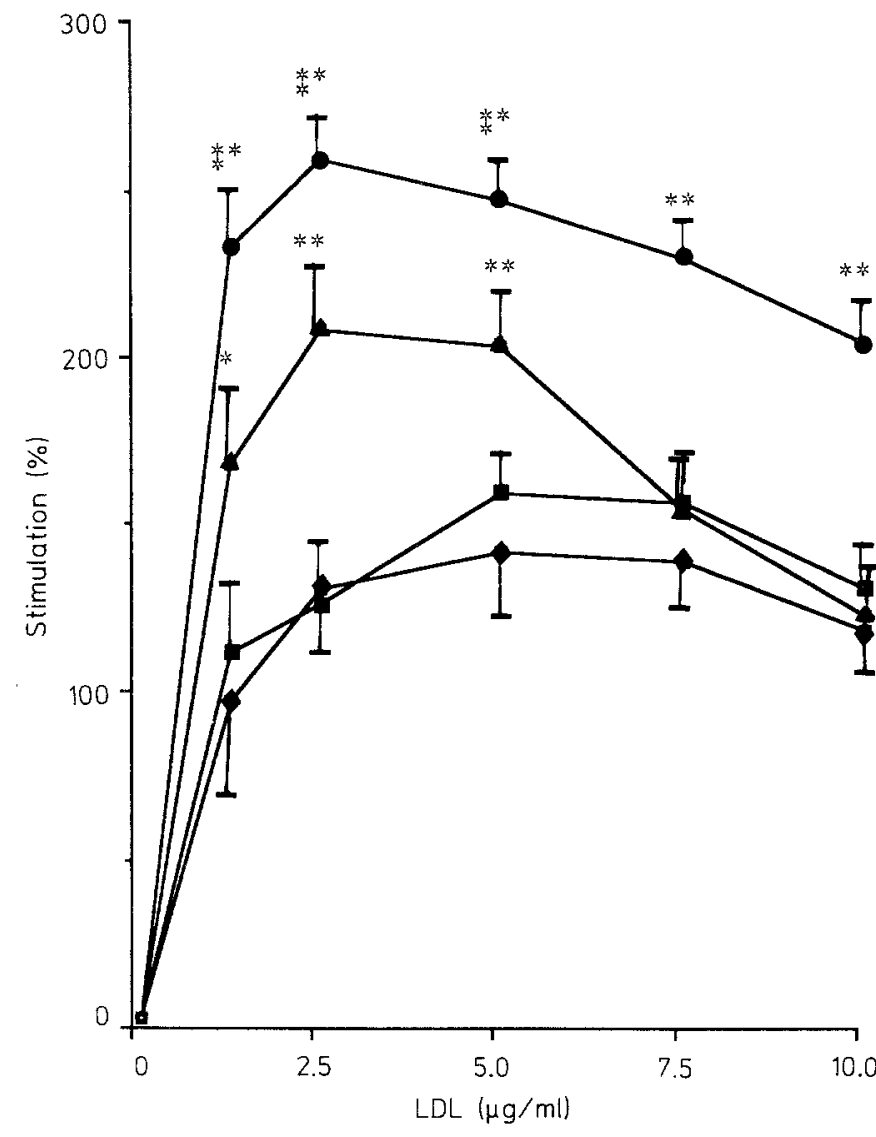

Fig.4. Enhancement by LDL of $\left[{ }^{3} \mathrm{H}\right]$-thymidine incorporation into mitogen-stimulated normal lymphocytes cultured for $72 \mathrm{~h}$ in lipoprotein-deficient medium and with endogenous cholesterol synthesis inhibited by mevinolin. Results expressed as \%-stimulation by LDL. Error bars indicate SEM. Significance levels $* *=p<0.002$, $*=p<0.02$ different from non-diabetic normocholesterolaemic or hypercholesterolaemic subjects. Multiple comparisons were performed. LDL from normocholesterolaemic non-diabetic subjects $(n=11)$ diamond; LDL from normocholesterolaemic Type 2 diabetic patients ( $n=14)$ square; LDL from hypercholesterolaemic non-diabetic subjects $(n=9)$ triangle; and LDL from hypercholesterolaemic Type 2 diabetic patients $(n=12)$ circle

inhibition of uptake of $19 \%, 30 \%$ and $36 \%$ while LDL, $30 \%$ glycosylated, at the same concentrations gave inhibition levels of $20 \%, 30 \%$ and $37 \%$ respectively.

\section{Cell proliferation}

With endogenous sterol synthesis inhibited by mevinolin and added LDL the only source of cholesterol available, incorporation of $\left[{ }^{3} \mathrm{H}\right]$-thymidine by PHA stimulated lymphocytes reflects cellular LDL uptake. All LDL preparations, tested under these circumstances, increased the incorporation of $\left[{ }^{3} \mathrm{H}\right]$-thymidine into mitogen-stimulated lymphocytes. The promotion of lymphocyte proliferation by LDL from the different patient categories varied and is shown in Figure 4. Addition of LDL from normocholesterolaemic, non-diabetic subjects resulted in approximately $100 \%$ increase in $\left[{ }^{3} \mathrm{H}\right]$-thymidine incorporation which was maximal at $5 \mu \mathrm{g} / \mathrm{ml} \mathrm{LDL}$ and declined slightly at $10 \mu \mathrm{g} / \mathrm{ml}$ LDL. LDL from Type 2 diabetic patients who

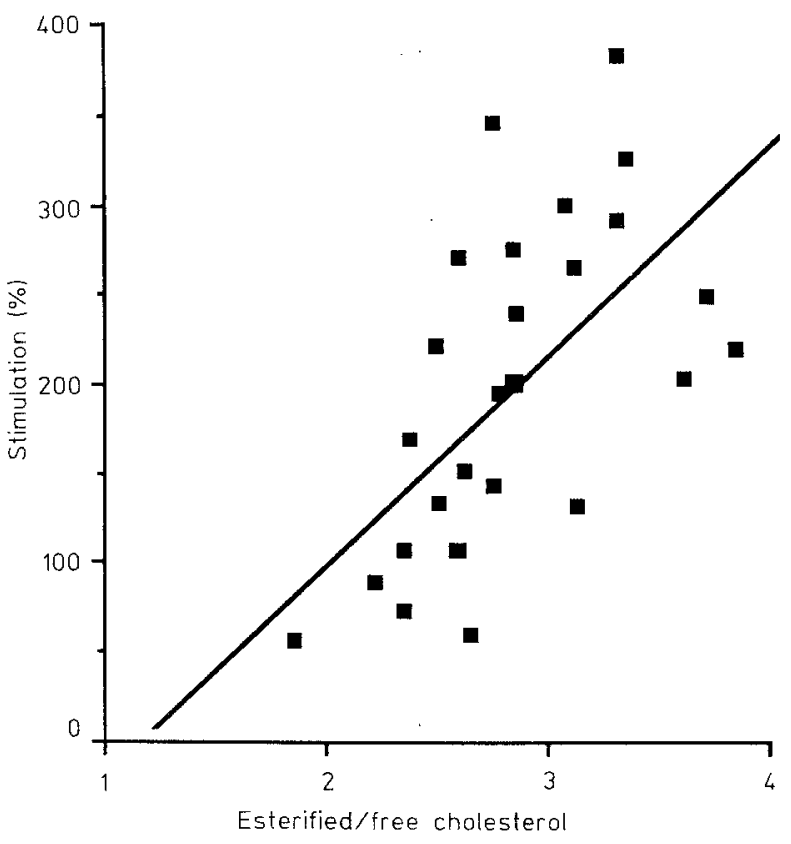

Fig. 5. Correlation between the esterified/free cholesterol ratio in LDL from Type 2 (non-insulin-dependent) diabetic patients $(n=26)$ and enhancement of $\left[{ }^{3} \mathrm{H}\right]$-thymidine incorporation into mitogen-stimulated normal lymphocytes. $(r=0.60, p<0.001)$

were not hypercholesterolaemic stimulated $\left[{ }^{3} \mathrm{H}\right]$-thymidine incorporation in a manner highly comparable to that of non-diabetic subjects. LDL from both Type 2 diabetic and non-diabetic hypercholesterolaemic patients, gave a significantly higher level of stimulation. This was most evident at low LDL concentrations $(<5 \mu \mathrm{g} / \mathrm{ml}$ LDL) and the greatest difference was seen when using LDL from hypercholesterolaemic patients who also had Type 2 diabetes. With these LDL samples stimulation of lymphocyte proliferation was more than double that using LDL from normocholesterolaemic subjects $(p<0.002)$. Furthermore, LDL from these hypercholesterolaemic Type 2 diabetic patients was significantly more stimulatory than LDL from their non-diabetic counterparts $(p<0.02)$. LDL from normocholesterolaemic Type 2 diabetic patients in good and poor metabolic control showed similar stimulation curves (data not shown). The enhanced stimulation of $\left[{ }^{3} \mathrm{H}\right]$-thymidine incorporation into lymphocytes by LDL from Type 2 diabetic patients was related to the esterified/free cholesterol ratio of the LDL which correlated positively $(r=0.6, p<0.001)$ with its ability to enhance $\left[{ }^{3} \mathrm{H}\right]$-thymidine uptake by PHAstimulated cells (Fig.5).

\section{Discussion}

This study has compared the efficacy of LDL isolated from Type 2 diabetic and non-diabetic patients, with and without hypercholesterolaemia, to regulate cholesterol metabolism in PHA-stimulated normal lymphocytes. Two aspects of LDL function were evaluated. Its ability to down-regulate de novo cholesterol synthesis as measured by $\left[{ }^{14} \mathrm{C}\right]$-acetate uptake into cells and, its capacity to de- 
liver cholesterol to cells whose endogenous cholesterol synthesis was blocked by mevinolin. A marked impairment of the capacity of exogenous LDL to suppress $\left[{ }^{14} \mathrm{C}\right]-$ acetate uptake into cellular cholesterol was observed using LDL from hypercholesterolaemic patients, both Type 2 diabetic and non-diabetic, relative to that isolated from normocholesterolaemic, diabetic patients in good metabolic control or non-diabetic subjects (Fig.2). This impaired capacity to regulate $\left[{ }^{14} \mathrm{C}\right]$-acetate uptake was particularly evident with LDL from Type 2 diabetic patients in poor metabolic control and was apparent even in Type 2 diabetic patients who were normocholesterolaemic but in poor glycaemic control. It has been shown that binding to the high affinity LDL receptor is impaired when the LDL molecule is modified by glycosylation [24] and the altered levels of glycosylation of LDL from some of our Type 2 diabetic patient categories were similar to those found by these workers. It has been shown in normal cells that LDL entering the cell only by the high affinity route regulates cholesterol synthesis [25]. It is possible therefore, that the altered ability of LDL from some of our patients to down-regulate cholesterol synthesis might be a manifestation of impaired receptor-mediated binding of glycosylated LDL by lymphocytes and the strong negative correlation shown here between the degree of LDL glycosylation and its capacity to suppress cellular cholesterol synthesis $(r=-0.74, p<0.001)$ may be indicative of this process.

It may be of interest that high levels of glycosylation of LDL from diabetic patients were accompanied by an increase in the esterified/free cholesterol ratio in the LDL particle (Fig.1). This may indicate that cholesterol ester transfer protein (CETP)-derived cholesterol ester is preferentially taken up by glycosylated LDL in vivo. Elevated levels of CETP present in the plasma of hyperlipidaemic patients have been shown to promote cholesterol ester transfer to apo B-containing lipoproteins [26]. Increased CETP activity has been reported in the plasma of Type 1 diabetic patients and the increase correlated positively with the $\mathrm{HbA}_{1}$ level [27] suggesting a link between hyperglycaemia and cholesterol esterification. Increased LDL cholesterol ester transfer between lipoproteins has been related to impaired LDL receptor binding. Zechner et al. [28] have showed that when the esterified/free cholesterol ratio was increased by incubating LDL with lecithin cholesterol acyl transferase (LCAT), it bound less well to the high affinity LDL receptor. Although the esterified cholesterol/triglyceride ratios of the LDL in some of the groups studied were different, in view of the mild degree of hypertriglyceridaemia observed in the study and the lack of any significant change in the triglyceride content of the LDL in the different groups studied, it would appear that the increase in cholesterol ester content of the LDL is the critical factor. The fact that, in this study, LDL from non-diabetic hypercholesterolaemic patients, which is not excessively glycosylated yet is a poor inhibitor of $\left[{ }^{14} \mathrm{C}\right]-$ acetate incorporation, also points to the increased esterified/free cholesterol ratio rather than glycosylation as a more likely cause for the defective regulation of cholesterologenesis both in the Type 2 diabetic and non-diabetic patient. This is supported by the finding that increasing
LDL glycosylation in vitro from $1.6 \%$ to $30 \%$ had no effect on $\left[{ }^{14} \mathrm{C}\right]$-acetate incorporation into cellular cholesterol.

$\left[{ }^{3} \mathrm{H}\right]$-thymidine incorporation into mevinolin-inhibited, mitogen-stimulated lymphocytes, cultured in LDS, has been shown to represent uptake of added LDL by the cell [29]. The decrease in $\left[{ }^{3} \mathrm{H}\right]$-thymidine uptake in the presence of LDL in concentrations greater than $5 \mu \mathrm{g} / \mathrm{ml}$ (Fig. 4) is consistant with earlier findings in our laboratory [5] and elsewhere [4] and may represent an additional immunoregulatory function for the LDL molecule. When comparing the ability of LDL from the various patient categories to stimulate $\left[{ }^{3} \mathrm{H}\right]$-thymidine uptake the significant differences $(p<0.002)$ were observed between hypercholesterolaemic Type 2 diabetic and non-diabetic subjects compared with their normocholesterolaemic counterparts. Dividing the patients into good or poor metabolic control groups did not influence the results. Reduced uptake of glycosylated LDL by the high affinity pathway has been shown to be accompanied by enhanced uptake by the non-specific pathway [24] and it is probable that this is the pathway taken by LDL from the Type 2 diabetic patients in poor metabolic control. LDL from patients who were hypercholesterolaemic, both Type 2 diabetic and non-diabetic, supported cell proliferation to a remarkably greater extent than normal in circumstances where endogenous cholesterol synthesis had been inhibited. If this stimulation represented increased delivery of cholesterol, it might imply that esterified cholesterol is preferentially taken up by the cell. On the other hand, cholesterol which is already esterified may favour cellular growth to a greater extent than free cholesterol. Such a possibility is suggested by the data presented in Figure 5. The fact that increased stimulation of cell proliferation by LDL from both Type 2 diabetic and non-diabetic hypercholesterolaemic patients was accompanied by diminished regulation of endogenous cholesterol synthesis again suggests that this LDL entered the cell by a pathway other than the high affinity LDL receptor route.

These data have indicated that poor glycaemic control changes LDL composition in such a way as to compromise its regulatory role in cellular cholesterologenesis. However, while this compromise was evident even in normocholesterolaemic Type 2 diabetic subjects, accompanying hypercholesterolaemia greatly exaggerated it and the similar results using LDL from hypercholesterolaemic patients in whom glycosylation was not increased, suggest that glycosylation per se may not adversely affect regulation of cholesterologenesis rather that it is the increased esterified/free cholesterol ratio in the LDL, secondary to glycosylation, which is the important factor. It seems probable that too much emphasis may have been placed on the regulatory effect of non-enzymatic glycosylation of LDL as an important control mechanism of cholesterol homeostasis in the diabetic patient [30].

These results suggest a common defect in the regulation of cellular cholesterol metabolism in diabetic and hypercholesterolaemic patients and assume considerable relevance in the light of the suggestion that cholesteryl ester enriched apo B containing lipoproteins are probably atherogenic [31]. 
Acknowledgements. This study was supported by grants from the Medical Research Council of Ireland and the Adelaide Hospital Diabetic Research fund.

\section{References}

1. Bennion LT, Grundy S (1977) Effect of diabetes mellitus on cholesterol metabolism in man. N Engl J Med 296: 1365-1371

2. Sosenko JM, Breslow JL, Miettinen OS, Gabbay KH (1980) Hyperglycaemia and plasma lipid levels: a prospective study of young insulin-dependent diabetic patients. $\mathrm{N}$ Engl J Med 302: 650-654

3. Goldstein JL, Brown MS (1977) The low-density lipoprotein pathway and its relation to atherosclerosis. Ann Rev Biochem 46: 897-930

4. Cuthbert JA, Lipsky PE (1983) Immunoregulation by low density lipoprotein in man: low density lipoprotein inhibits mitogenstimulated human lymphocyte proliferation after initial activation. J Lipid Res 24: 1512-1524

5. Owens D, Collins P, Johnson A, Tomkin G (1988) Regulation of mitogen-induced lymphocyte transformation by low density lipoprotein. Biochem Soc Trans 16: 202-203

6. Jan-Kan Chen, Hoshi H, McClure DB, McKeehan WL (1986) Role of lipoproteins in growth of human adult arterial endothelial and smooth muscle cells in low lipoprotein-deficient serum. J Cell Physiol 129: 207-214

7. Kim HK, Kurup IV (1982) Non-enzymatic glycosylation of human plasma low-density lipoprotein. Evidence for in vitro and in vivo glycosylation. Metabolism 31:348-353

8. Steinbrecher UP, Witztum JL (1984) Glycosylation of low-density lipoproteins to an extent comparable to that seen in diabetes slows their catabolism. Diabetes 33: 130-134

9. Chait A, Eisenberg S, Steinmetz A, Albers JJ, Bierman EL (1984) Low-density lipoproteins modified by lipid transfer protein have altered biological activity. Biochim Biophys Acta 795: 314-325

10. Hiramatsu K, Bierman EL, Chait A (1985) Metabolism of lowdensity lipoprotein from patients with diabetic hypertriglyceridaemia by cultured human skin fibroblasts. Diabetes 34 : 8-14

11. Mahley RW, Innerarity TL, Pitas RE, Weisgraber KH, Brown JH, Gross E (1977) Inhibition of lipoprotein binding to cell surface receptors of fibroblasts following selective modification of arginyl residues in arginine-rich and B apoproteins. J Biol Chem 252: 7279--7287

12. Maher V, Devery RAM, Collins PB, Johnson AH, Tomkin GH (1987) Relationship between low density lipoprotein cholesterol and 3-hydroxy-3-methylglutaryl coenzyme A reductase activity in monocytes from Type 2 (non-insulin-dependent) diabetic patients. Diabetologia 30:553 A (Abstract)

13. Havel RA, Eder HM, Bragdon JH (1955) The distribution and chemical composition of ultracentrifugally separated lipoproteins in human serum. J Clin Invest 34: 1345-1353

14. Chapman MJ, Goldstein S, Lagrange D, Laplaud PM (1981) A density gradient, ultracentrifugal procedure for isolation of the major lipoprotein classes from human serum. J Lipid Res 22: 339-358

15. Chapman MJ, Laplaud PM, Luc G, Forgez P, Bruckert E, Goulinet S, Lagrange D (1988) Further resolution of the low density lipoprotein spectrum in normal human plasma: physiochemical characteristics of discrete subspecies separated by density gradient ultracentrifugation. J Lipid Res 29: 442-458

16. Naito HK, Wada M, Erhart LA, Lewis LA (1973) Polyacrylamide-gel disc-electrophoresis as a screening procedure for serum lipoprotein abnormalities. Clin Chem 19:228-234

17. Markwell MAK, Haas SM, Bieber LL, Tolbert NE (1978) A modification of the Lowry procedure to simplify protein deter- mination in membrane and lipoprotein samples. Anal Biochem 87: 206-210

18. Lyons TJ, Klein RL, Baynes JW, Stevenson HC, Lopes-Virella MF (1987) Stimulation of cholesterol ester synthesis in human monocyte-derived macrophages by low-density lipoproteins from Type 1 (insulin-dependent) diabetic patients: the influence of non-enzymatic glycosylation of low-density lipoprotein. Diabetologia 30: $916-923$

19. Jack CM, Sheridan B, Kennedy L, Stout RW (1988) Non-enzymatic glycosylation of low-density lipoproteins. Results of an affinity chromatography method. Diabetologia 31: 126-128 (Letter)

20. Mistry P, Millar NE, Laker M, Hazzard WR, Lewis B (1981) Individual variation in the effects of dictary cholesterol on plasma lipoproteins and cellular cholesterol homeostasis in man. J Clin Invest 67: 493-502

21. Boyum A (1968) Isolation of mononuclear cells and granulocytes from human blood. J Clin Lab Invest 97 [Suppl 21]: 77-89

22. Ho YK, Faust JR, Bilheimer DW, Brown MS, Goldstein JL (1977) Regulation of cholesterol synthesis by low density lipoprotein in isolated human lymphocytes. J Exp Med 145: 15311549

23. Cuthbert JA, Lipsky PE (1981) Sterol metabolism and lymphocyte responsiveness: inhibition of endogenous sterol synthesis prevents mitogen-induced human $\mathrm{T}$ cell proliferation. J Immunol 126: 2093-2099

24. Lopes-Virella MF, Klein RL, Lyons TJ, Stevenson HC, Witztum JL (1988) Glycosylation of low density lipoprotein enhances cholesteryl ester synthesis in human monocyte-derived macrophages. Diabetes 37: 550-557

25. Brown MS, Goldstein JL (1974) Familial hypercholesterolaemia: defective binding of lipoproteins to cultured fibroblasts associated with impaired regulation of 3-hydroxy-3-methylglutaryl coenzyme A reductase activity. Proc Natl Acad Sci 71: 788792

26. Tall A, Granot E, Brocia R, Tabas I, Hesler C, Williams K, Denke M (1987) Accelerated transfer of cholesterol esters in dyslipidaemic plasma: role of cholesteryl ester transfer protein. J Clin Invest 79: 1217-1225

27. Dullaart RPF, Groener JEM, Dikkeschei LD, Erkelens DW, Doorenbos H (1989) Increased cholesterylester transfer activity in complicated Type 1 (insulin-dependent) diabetes mellitus -its relationship with serum lipids. Diabetologia 32:14-19

28. Zechner R, Dieplinger H, Roscher A, Krempler F, Kostner G (1982) The role of lecithin: cholesterol acyltransferase for the low density lipoprotein composition and specific binding to the $B$ receptor. Biochem Biophys Acta 712: 433-435

29. Cuthbert JA, Lipsky PE (1989) Identification of low density lipoprotein receptor abnormalities by assaying functional receptors on proliferating lymphocytes. Arteriosclerosis [Suppl 1] 9: $43-49$

30. Brownlee M, Cerami A, Vlassara H (1988) Advanced glycosylation end products in tissue and the biochemical basis of diabetic complications. N Engl J Med 318: 1315-1321

31. Tall A (1986) Plasma lipid transfer proteins. J Lipid Res 27: 361367

Received: 28 April 1989

and in revised form: 15 September 1989

Prof. G. Tomkin

The Adelaide Hospital

Peter Street

Dublin 8

Ireland 